\title{
Supplementary diet components of little auk chicks in two contrasting regions on the West Spitsbergen coast
}

\author{
Rafał Boehnke $\cdot$ Marta Gluchowska $\cdot$ Katarzyna Wojczulanis-Jakubas • \\ Dariusz Jakubas • Nina J. Karnovsky • Wojciech Walkusz • \\ Slawomir Kwasniewski • Katarzyna Błachowiak-Samołyk
}

Received: 11 April 2014/Revised: 25 August 2014/Accepted: 26 August 2014/Published online: 26 September 2014

(C) The Author(s) 2014. This article is published with open access at Springerlink.com

\begin{abstract}
The complete diet composition structure of the most numerous planktivorous sea bird, little auk (Alle alle), in the European Arctic, is still not fully recognized. Although regular constituents of little auk chick diets, the copepods, Calanus glacialis and C. finmarchicus have been previously relatively well described, more taxa were frequent ingredients of the bird's meals. Therefore, the role of the little auks supplementary diet components (SDCs) at two colonies in the Svalbard Archipelago, Hornsund and Magdalenefjorden, in 2007-2009, is a main subject of this comparative study. Because the SDCs often consisted of scarce but large zooplankters, this investigation was focused on biomass as a proxy of the SDCs' energy input. Although the total biomass of the food delivered to chicks in both colonies was similar, in Magdalenefjorden, the proportion of SDCs was twice that found in Hornsund. The main SDCs in Hornsund were Decapoda larvae (with predominating Pagurus pubescens) and Thysanoessa
\end{abstract}

R. Boehnke $(\bowtie) \cdot$ M. Gluchowska · W. Walkusz ·

S. Kwasniewski · K. Błachowiak-Samołyk

Institute of Oceanology Polish Academy of Sciences,

Powstańców Warszawy 55, 81-712 Sopot, Poland

e-mail: rafalb@iopan.gda.pl

K. Wojczulanis-Jakubas · D. Jakubas

Department of Vertebrate Ecology and Zoology, University

of Gdańsk, Wita Stwosza 59, 80-308 Gdańsk, Poland

N. J. Karnovsky

Department of Biology, Pomona College, 175 W. 6th St.,

Claremont, CA 91711, USA

W. Walkusz

Freshwater Institute, Fisheries and Oceans Canada, 501

University Crescent, Winnipeg, MB R3T 2N6, Canada inermis, whereas the main SDCs in Magdalenefjorden were C. hyperboreus and Apherusa glacialis. Previous investigations, which indicated lipid richness of SDCs, together with our ecological results from the colonies, suggest that this category might play a compensatory role in little auk chick diets. The ability to forage on diverse taxa may help the birds to adapt to ongoing Arctic ecosystem changes.

Keywords Little auk - Feeding ecology - Arctic . Zooplankton $\cdot$ Svalbard $\cdot$ Climate change

\section{Introduction}

The little auk (Alle alle) is one of the most numerous seabirds of the northern Atlantic (Stempniewicz 2001), breeding exclusively in the High Arctic (Isaksen and Gavrilo 2000). It is a planktivorous bird with metabolic rates considered as one of the highest among seabirds (Gabrielsen et al. 1991; Konarzewski et al. 1993). Due to extremely high energy demands, little auks rely almost exclusively on lipid-rich zooplankton associated with cold Arctic waters (Kwasniewski et al. 2012). Since foraging little auks prefer Arctic water masses, avoiding the Atlantic ones with smaller and less profitable zooplankton community, this species is considered as an important indicator of changes in the marine environment (Karnovsky et al. 2003; Jakubas et al. 2007; Stempniewicz et al. 2007; Harding et al. 2008). For that reason, the breeding ecology of the little auk, including aspects of feeding strategy and chick diet composition, has been frequently investigated in the context of an ongoing climate-induced changes in the Arctic (e.g., Jakubas et al. 2007; Harding et al. 2009; Fort et al. 2010; Karnovsky et al. 2010; Kwasniewski et al. 2010; Jakubas et al. 2011; Kwasniewski et al. 2012). 
Previous studies have shown that copepods are the most important components in the diet of little auk chicks raised in the large colonies on Svalbard, i.e., Bjørnøya (Węsławski et al. 1999), Isfjorden (Steen et al. 2007), Hornsund (Karnovsky et al. 2003; Wojczulanis et al. 2006; Jakubas et al. 2007; Kwasniewski et al. 2010; Jakubas et al. 2011; Kwasniewski et al. 2012) and Magdalenefjorden (Kwasniewski et al. 2010; Jakubas et al. 2011; Kwasniewski et al. 2012). In particular, Calanus glacialis, a highly caloric calanoid copepod associated with cold Arctic water, was found to be the most important energy source for birds from Svalbard colonies. Calanus finmarchicus is of secondary importance. This copepod has lower energy content and is associated with warm Atlantic waters (e.g., Kwasniewski et al. 2010 and citations therein). Although many other zooplankters such as amphipods, euphausiids, decapods, ostracods, gastropods, cephalopods, and polychaetes have been reported to occur in the diet of the little auk (e.g., Wesławski et al. 1999; Karnovsky et al. 2003; Wojczulanis et al. 2006; Steen et al. 2007), the role of such supplementary diet components (hereafter SDCs) has never been a subject of a separate, detailed investigation. The purpose of this study was to assess and compare the role of the SDCs in chick diets of little auks from the years 2007-2009 in the two breeding colonies with contrasting oceanographic conditions in order to provide a more complete understanding of the bird's feeding biology.

\section{Materials and methods}

Study area

Data on diet composition were collected in 2007-2009 at two large little auk colonies located on the west coast of Spitsbergen in Hornsund (Ariekammen slope, $77^{\circ} 00^{\prime} \mathrm{N}$, $15^{\circ} 31^{\prime} \mathrm{E}$ ) and Magdalenefjorden (Høystakken and Alkekongen slopes $79^{\circ} 35^{\prime} \mathrm{N}, 11^{\circ} 05^{\prime} \mathrm{E}$ ).

The Hornsund area is influenced by two currents; the coastal Sørkapp current providing cold and less saline Arctic water and the West Spitsbergen Current (WSC) transporting warmer, more saline Atlantic water (Piechura et al. 2001; Cottier et al. 2005; Piechura and Walczowski 2009). In the Magdalenefjorden area, the relatively warm and saline water of the WSC is present over the large part of the shelf, while fresher and colder Arctic type water travels as an anticyclonic coastal current, visible as a narrow flow close to the coast (Kwasniewski et al. 2010; Jakubas et al. 2011).

\section{Collection of materials}

Food loads were taken from adult birds transporting food to their offspring throughout the breeding season. In total, 173 diet food samples were collected in Hornsund $(55,55$, and 63) and 170 in Magdalenefjorden (41, 70, and 59) in 2007, 2008, and 2009, respectively. The birds were captured randomly in the colony by mist nets or noose carpets and the contents of their gular pouch were gently scooped out with a spoon. Each diet sample was put in a separate plastic bag and preserved in $4 \%$ borax-buffered formaldehyde. General diet results from Hornsund and Magdalenefjorden from 2007 to 2009 were already presented in Kwasniewski et al. (2010, 2012), Fort et al. (2010), Harding et al. (2011), Jakubas et al. (2011), Kidawa et al. (2014), Hovinen et al. (2014), and Karnovsky et al. (2010).

\section{Laboratory processing and data analyses}

All samples collected from the adult little auks in the colonies were subjected to quantitative and qualitative laboratory analyses following the procedures described in Kwasniewski et al. (2010). Due to a lack of inter-annual differences, data from the 3 years of observations were pooled to allow comparisons between the two colonies. "Supplementary diet components" (SDCs) were defined as all zooplankters found in little auk chick diets, except for C. glacialis and C. finmarchicus, which are known to be the two main components of their diet (Karnovsky et al. 2003, 2010; Kwasniewski et al. 2010). Because the importance of SDCs is related to the amount of energy they can provide, we used their dry mass instead of abundance to investigate their role and compare it between the colonies. To compare the chick meals from different colonies, $\chi^{2}$ test for independence was conducted. The proportions of particular items in diet components (Hornsund colony vs. Magdalenefjorden colony), as well as the proportions of the selected SDCs in the total SDCs biomass between colonies (Hornsund vs. Magdalenefjorden), were compared for yearly pooled samples using $\chi^{2}$ test for independence $(2 \times 2$ table $)$. The total biomass of chick meals, as well as the biomass of SDCs in the chick meals, were compared using Mann-Whitney $U$ test. To compare the frequency distribution of SDCs contribution to the chick meals, biomass between the colonies, nonparametric KolmogorovSmirnov two-samples test was used. Statistical analyses were done using STATISTICA 10.0 (StatSoft, Inc.) following recommendation by Sokal and Rolf (1981), and the significance level for all tests used was $p<0.05$ (Fig. 1).

\section{Results}

Taxonomic composition of little auk chick diet

A total of 36 zooplankton taxa were recorded in the diet of little auk chicks during the whole study period in the two 


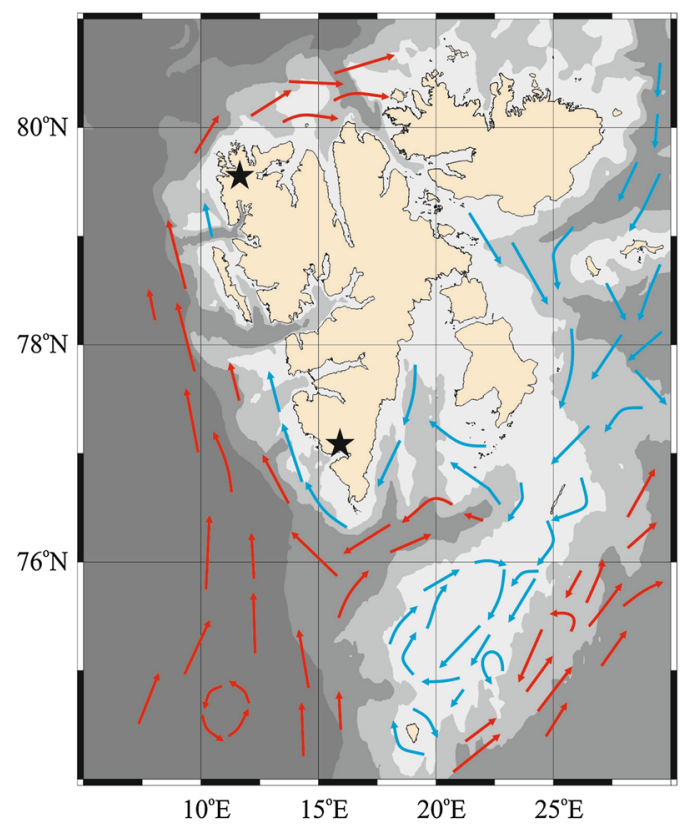

Bathymetry $[\mathrm{m}]$

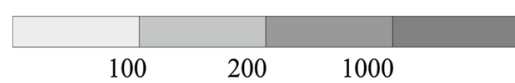

Little auk colony $\rightarrow$ Arctic Water $\rightarrow$ Atlantic Water

Fig. 1 Study area in the Spitsbergen region with sea current pattern (after Loeng and Drinkwater 2007, modified), bathymetry (depth contours and gray shading), the locations of little auk colonies (black stars)

colonies combined. Of that, nine taxa made up $99 \%$ of the total diet biomass. Two main diet components: Calanus. glacialis and C. finmarchicus were present in 96 and $95 \%$ of the diet samples, respectively (data not shown). Seven other taxa most frequently observed in diet samples were as follows: C. hyperboreus (52\% of all diet samples), Apherusa glacialis (17\%), Thysanoessa inermis (23\%), Decapoda larvae (excluding Pagurus pubescens larvae, $51 \%)$, Pagurus pubescens larvae (59\%), Themisto libellula (36\%), and T. abyssorum (73\%). The remaining 27 taxa (Thysanoessa raschii and T. longicaudata, fish larvae, Paraeuchaeta spp., Hyperoche medusarum, Hyas araneus larvae, Metridia longa, Limacina helicina, Gammarus wilkitzkii, and Eukrohnia hamata, together made up $1 \%$ of the diet biomass and were therefore combined into one group of the SDCs, the "remaining category".

\section{Biomass composition of chick diet}

Dry mass (DM) of the food delivered to chicks was similar in Hornsund $(\min =21.5 \mathrm{mg}, \quad \max =2,535.2 \mathrm{mg} ; \quad \mathrm{Me}=$ $902.7 \mathrm{mg} \mathrm{DM}$ meal $\left.^{-1} n=173\right)$ and Magdalenefjorden $(\min =83.1 \mathrm{mg}, \max =2,177.8 \mathrm{mg} ; \mathrm{Me}=925.3 \mathrm{mg} \mathrm{DM}$ meal $^{-1} n=170$; Mann-Whitney $U$ test, $\mathrm{Z}_{173,170}=-0.83$, $p=0.406$ ). Similarly, no differences were found in the mean biomass of the SDCs between Hornsund (59.7 mg DM $\mathrm{meal}^{-1}$ ) and Magdalenefjorden (40.7 mg DM meal ${ }^{-1}$; $\mathrm{Z}_{173,170}=-1.69, p=0.09$ ). The food delivered to chicks by parent birds in the Hornsund colony differed from the food delivered by the birds in Magdalenefjorden with regard to biomass contributions of prey items (test $\chi^{2}, \chi^{2}=9.71$ $d f=2, p=0.008$ : Fig. 2a, b). In Magdalenefjorden, the chick meals had a lower proportion of $C$. glacialis ( $\chi^{2}$ test, $\left.\chi_{1}^{2}=14,820.1, p<0.001\right)$, a higher proportion of $C$. finmarchicus $\left(\chi_{1}^{2}=1,919.8, p<0.001\right)$ and the proportion of SDCs twice of that found in Hornsund colony $\left(\chi^{2}\right.$ test, $\left.\chi_{1}^{2}=11,331.8, p<0.001\right)$.

\section{Contribution of SDCs in chick diet}

The contributions of different prey items to the SDCs biomass differed significantly between the two studied colonies (test $\chi^{2}, \chi^{2}=110.9 d f=7, p<0.001$ : Fig. 2a, b). The main components of SDCs in Hornsund were: Pagurus pubescens larvae (29\% of SDCs biomass), Thysanoessa inermis (28\%), Decapoda larvae (21\%), amphipods Themisto libellula and T. abyssorum (14\%), as well as C. hyperboreus (3\%) (Fig. 2a). In Magdalenefjorden, the predominant SDCs taxa were $C$. hyperboreus (47\%), Apherusa glacialis (25\%), Decapoda larvae (8\%), T. inermis (6\%), T. abyssorum and T. libellula (10\%), and Pagurus pubescens larvae (1\%) (Fig. 2b). The proportions of each of the above-mentioned food items to the total SDCs biomass differed between the colonies $\left(\chi^{2}\right.$ tests, $p<0.001$, individual test values not shown).

Intercolony differences in the contribution of SDCs in chick diet

Frequency distribution of SDCs contribution to the total chick meals biomass was different between the colonies (Kolmogorov-Smirnov test, $p<0.001$; Fig. 3a, b). In the diet samples collected in Hornsund colony, the SDCs most frequently made up $<10 \%$ of the diet, and $84 \%$ of the samples had the SDCs contribution lower or equal to $30 \%$. In Magdalenefjorden, the most frequently found class of SDCs contribution was also $<10 \%$, but only $58 \%$ of the samples had up to $30 \%$ of the SDCs. Only in $1 \%$ of the samples from Hornsund and almost in $20 \%$ from Magdalenefjorden the SDCs contribution was larger than $90 \%$.

Among the samples with SDCs contribution $<30 \%$, the most important food items in Hornsund were Pagurus pubescens and Decapoda larvae (Fig. 3a), whereas in Magdalenefjorden the main item was Calanus hyperboreus (Fig. 3b). Among the samples with SDCs contribution $>30 \%$, the most important food items in Hornsund were 
(a)

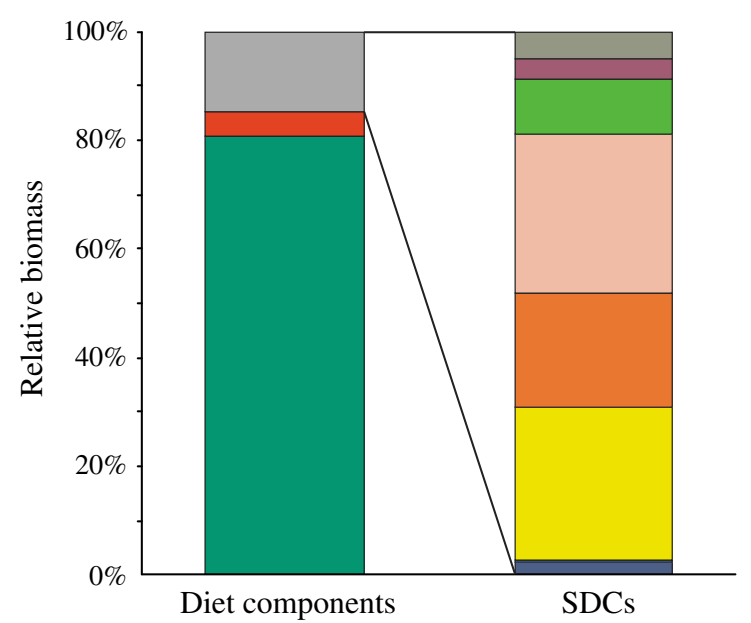

(b) Magdalenefjorden colony $(n=170)$

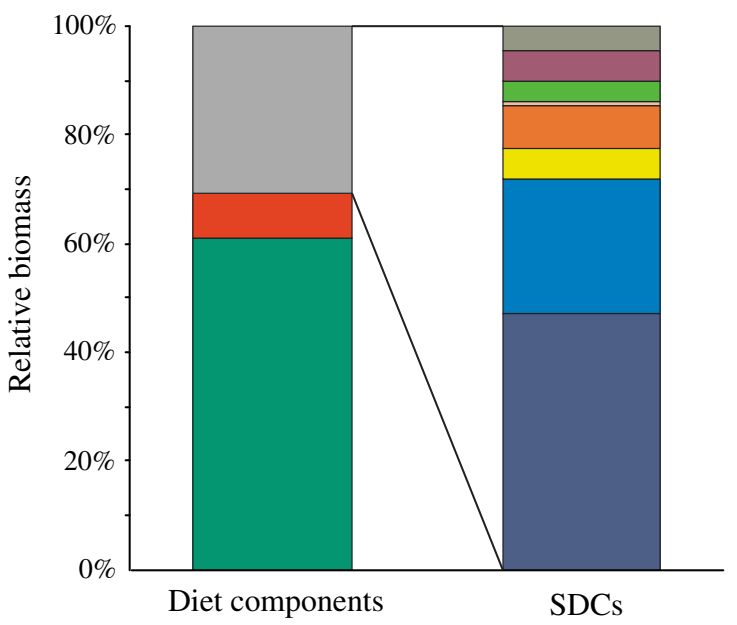

Diet components

Calanus finmarchicus

Calanus glacialis

SDCs

\section{Supplementary diet components (SDCs)}

Calanus hyperboreus

Apherusa glacialis

Thysanoessa inermis

Decapoda larvae

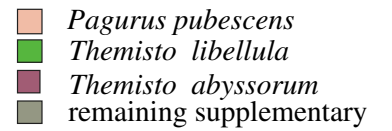

Fig. 2 Relative composition of zooplankton prey biomass in the food delivered to little auk chicks in a Hornsund and b Magdalenefjorden colonies in 2007-2009, combined, with details of the biomass composition of birds supplementary diet components (SDCs)
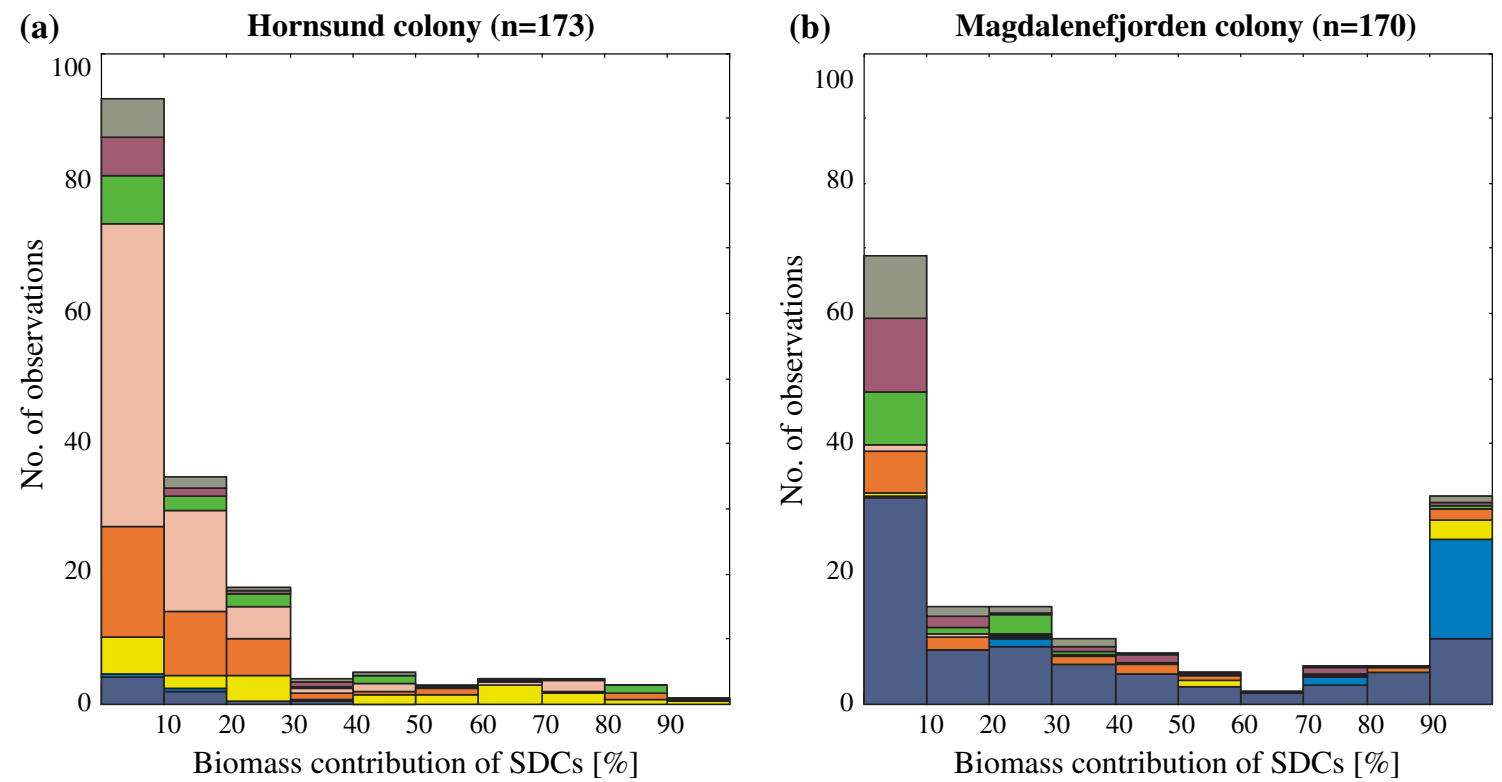

Supplementary diet components (SDCs)
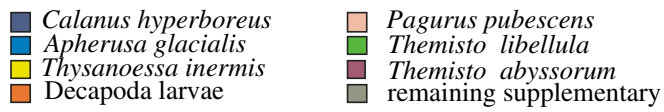

Fig. 3 Frequency distribution of contributions to biomass of supplementary diet components (SDCs) for Hornsund (a) and Magdalenefjorden (b)

euphausiids (predominantly T. inermis) while in Magdalenefjorden they were A. glacialis and $C$. hyperboreus. What is more, in Magdalenefjorden, A. glacialis alone made up the bulk of the biomass in the samples with $>90 \%$ contribution of the SDCs to the little auk chick diet. 


\section{Discussion}

An overall diversity of taxa found in little auk chick diet in the two study colonies (36 taxa) was similar to that reported previously from Hornsund (35 taxa; Karnovsky et al. 2003), but was higher than in Isfjorden, western coast of Spitsbergen (23 taxa; Steen et al. 2007), and substantially higher than in northwest Greenland (14 taxa; Pedersen and Falk 2001), BjØrnØya (18 taxa; Węsławskiet al. 1999) and Franz Josef Land Archipelago (13 taxa; Węsławski et al. 1994). Greater diversity of taxa in the diet found in our study compared to some other colonies may reflect more intense sampling effort. This, in turn, may be attributed to more complex oceanographic conditions in the vicinity of the two studied colonies. Presence of the two greatly different water masses (influenced by Arctic and Atlantic currents) results in co-occurrence of two distinct zooplankton assemblages-Arctic and boreal—of which each contains own zooplankton diversity (e.g., Karnovsky et al. 2003; Kwasniewski et al. 2010).

Calanus hyperboreus was the dominant SDC of little auk chicks' meals in the Magdalenefjorden colony with $47 \%$ share in the SDCs biomass (15\% of total diet biomass). In a study from East Greenland, this copepod was the dominant component of chick diets with biomass consisting of 36-58\% of the total diet (Fort et al. 2010; Karnovsky et al. 2010). The prevalence of the last-mentioned component was also observed in northwest Greenland (Frandsen et al. 2014). This taxon exhibits betterdeveloped lipid storage strategy, and is much larger than its two counterparts, C. finmarchicus and C. glacialis (Hagen and Auel 2001). Adult C. hyperboreus inhabits mostly deep waters, but their immature copepodid stages occupy surface waters (Hirche et al. 2006), therefore they can serve as an available and very nourishing food source for diving little auks.

The ice-associated amphipod, Apherusa glacialis, was the second most important SDC in the little auk chicks' food in Magdalenefjorden. This amphipod was present in $20 \%$ of the samples from that colony. In fact, $9 \%$ of the food loads consisted exclusively of $A$. glacialis. Our study confirmed the previous finding that little auks breeding in Magdalenefjorden forage regularly in the marginal sea ice zone, located even up to $110 \mathrm{~km}$ from the colony (Jakubas et al. 2012, 2013), where this ice-associated amphipod can be found (Jakubas et al. 2011). Apherusa glacialis helps meet the high energy demands of little auks due to its high lipid content (Scott et al. 1999). The low share of A. glacialis in the little auk diet in Hornsund (Fort et al. 2010) was also confirmed in our study. Higher abundance of $A$. glacialis was found in little auk food loads in Hornsund in 2004 when the sea ice was observed in the adjacent foraging area (Jakubas et al. 2007). The higher importance
(32\% of all prey items biomass) of ice-associated fauna in the diet of little auks from East Greenland (Fort et al. 2010) is most likely related to the proximity of the sea ice habitat in this area. The situation of the birds from the colony in Magdalenefjorden (this study), where $8 \%$ of the total diet components biomass (comprising $25 \%$ of the SDCs biomass) was made up by the ice associated prey item, suggests that birds from the colony could forage in the iceedge area.

Amphipods of Themisto genus were also noticeable SDCs in the food loads of the little auk chicks (14\% in Hornsund and $10 \%$ in Magdalenefjorden). Similarly, Themisto equaled to $17 \%$ of SDCs biomass have been reported in the little auk diet at Hakluyt Island (northwestern Greenland, Pedersen and Falk 2001). In the present study, the contribution of $T$. libellula was higher in Hornsund (10\% of SDCs biomass) (Fig. 2a), while $T$. abyssorum in Magdalenefjorden (6\%) (Fig. 2b). Due to the relatively high amount of lipids, mainly wax esters (Auel et al. 2002), amphipods from genus Themisto play an important role in the diet of different seabirds like the Brunnich's guillemot (Uria lomvia) and black-legged kittiwake (Rissa tridactyla) (Lønne and Gabrielsen 1992).

In Hornsund, Pagurus pubescens was the predominant SDC, with $29 \%$ share in SDCs biomass. In the previous studies in Hornsund, this prey item made up 2 and $8 \%$ of the total chicks diet biomass (Karnovsky et al. 2003 and Fort et al. 2010, respectively). During our investigation, it constituted only 4 and $1 \%$ of the total chick diet biomass in Hornsund and Magdalenefjorden, respectively. Although $P$. pubescens is relatively low caloric $\left(\sim 3 \mathrm{kcal} \mathrm{g}^{-1} \mathrm{DW}\right.$; according to Wacasey and Atkinson 1987), it seemed to be attractive prey for little auks likely because of its high availability near the Hornsund colony (Boehnke, unpubl.).

The euphausiid Thysanoessa inermis, found in the chick diets in our study, is more tolerant to colder water than its shallow-water and less-energetic counterpart T. raschii (Falk-Petersen et al. 1982; Hagen and Auel 2001). Thysanoessa inermis is associated with Arctic waters and in our study this species was a considerable contributor to SDCs biomass $(28 \%)$ of the little auk's diet in Hornsund. In the birds diet from Isfjorden, only a few individuals of Thysanoessa spp. were observed (Steen et al. 2007), but in the Franz Josef Archipelago, T. inermis constituted $\sim 11 \%$ of the total little auk's prey biomass (Węsławski et al. 1994).

Although in over half of the diet samples SDCs constituted only up to $10 \%$ of total chicks diet biomass, in 25 diet samples (constituting $15 \%$ of samples) taken in Magdalenefjorden those predominant SDCs ( $C$. hyperboreus and A. glacialis) constituted almost the whole sample (Fig. 3b).

The high frequency of occurrence of ice-associated fauna in the diet samples (our study) seems to confirm the 
previous assumption that little auks breeding in West Spitsbergen coast are able to modulate their feeding ecology depending on the temporal availability of their prey and also to exploit a wide range of prey (Karnovsky et al. 2008; Fort et al. 2010). The latest study of Hovinen et al. (2014) revealed that provisioning rates in little auks in two colonies in West Spitsbergen (including Magdalenefjorden) did not influence the chick's probability to fledge. Additionally, the same investigation showed that sea surface temperature was negatively correlated with fledging probability. This was likely related to the prey availability and quality in the little auk's foraging grounds. Thus, in our study, little auks from Magdalenefjorden most probably compensated lower availability of preferred $C$. glacialis on the adjacent foraging grounds (data not shown) by delivering other prey items, in that some energy-rich species, which was possible due to the relatively close distance to the marginal sea ice zone. This flexibility may help little auks to adapt to the expected ecosystem variability due to climate change by feeding on novel zooplankton species, which may increase in the North Atlantic as a result of global warming (Fort et al. 2010).

Acknowledgments This study was supported by a grant from Norway through the Norwegian Financial Mechanisms, project $\mathrm{Nr}$ PNRF-234-AI-1/07(ALKEKONGE), National Science Foundation, (OPP grant \# 0612504). This research received additional support from the SYNTHESYS Project http://www.synthesys.info/(DK-TAF2152) financed by European Community Research Infrastructure Action under the FP7 "Capacities" Program and from Polish National Science Centre (3088/SEAPOP/2014/2). We thank Nell Baldwin, Mateusz Barcikowski, Zachary Brown, Derek Buchner, Lech and Wojciech Iliszko, Julia Gleichman, Gosia Jakimiak, Liliana KeslinkaNawrot, Dorota Kidawa, Laurel McFadden, Adam Nawrot, Anna Kośmicka, Jan Samołyk and Derek Young for assistance in the field. We acknowledge the captain and the crew of the R/V Oceania (Institute of Oceanology Polish Academy of Sciences). Diet samples were collected with permission from the Governor of Svalbard and the Norwegian Animal Research Authority.

Open Access This article is distributed under the terms of the Creative Commons Attribution License which permits any use, distribution, and reproduction in any medium, provided the original author(s) and the source are credited.

\section{References}

Auel H, Harjes M, Rocha R, Stubing D, Hagen W (2002) Lipid biomarkers indicate different ecological niches and trophic relationships of the Arctic hyperid amphipods Themisto abyssorum and T. libellula. Polar Biol 25:374-383

Cottier F, Tverberg V, Inall M, Svendsen H, Nilsen F, Griffiths C (2005) Water mass modification in an arctic fjord through crossshelf exchange: the seasonal hydrography of Kongsfjorden, Svalbard. J Geophys Res 110:1-18

Falk-Petersen S, Sargent JR, Hopkins CCE, Vaja B (1982) Ecological investigations on the zooplankton community of Balsfjorden, northern Norway: lipids in the euphausids Thysanoessa raschii and T. inermis during spring. Mar Biol 68:97-102

Fort J, Cherel Y, Harding AMA, Welcker J, Jakubas D, Steen H, Karnovsky NJ, Gremillet D (2010) Geographic and seasonal variability in the isotopic niche of little auks. Mar Ecol Prog Ser 414:293-302

Frandsen MS, Fort J, Rigét FF, Galatius A, Mosbech A (2014) Composition of chick meals from one of the main little auk (Alle alle) breeding colonies in northwest Greenland. Polar Biol. doi:10.1007/s00300-014-1491-0

Gabrielsen GW, Taylor JRE, Konarzewski M, Mehlum M (1991) Field and laboratory metabolism and thermoregulation in Dovekies (Alle alle). Auk 108:71-78

Hagen W, Auel H (2001) Seasonal adaptations and the role of lipids in oceanic zooplankton. Zoology 104:313-326

Harding AMA, Hobson KA, Walkusz W, Dmoch K, Karnovsky NJ, Van Pelt TI, Lifjeld JT (2008) Can stable isotope $\left(\delta^{13} \mathrm{C}\right.$ and $\delta^{15} \mathrm{~N}$ ) measurements of little auk (Alle alle) adults and chicks be used to track changes in high-Arctic marine foodwebs? Polar Biol 31:725-733

Harding AMA, Egevang C, Walkusz W, Merkel F, Blanc S, Grémillet D (2009) Estimating prey capture rates of a planktivorous seabird, the little auk (Alle alle), using diet, diving behaviour, and energy consumption. Polar Biol 32:785-796

Harding AMA, Welcker J, Steen H, Hamer KC, Kitaysky AS, Fort J, Talbot SL, Cornick LA, Karnovsky NJ, Gabrielsen GW, Grémillet D (2011) Adverse foraging conditions may impact body mass and survival of a high arctic seabird. Oecologia 167:49-59

Hirche HJ, Muyakshin S, Klages M, Auel H (2006) Aggregation of the Arctic copepod Calanus hyperboreus over the ocean floor of the Greenland Sea. Deep Sea Res 53:310-320

Hovinen JH, Wojczulanis-Jakubas K, Jakubas D, Hop H, Berge J, Kidawa D, Karnovsky NJ, Steen H (2014) Fledging success of little auks in the high Arctic: do provisioning rates and the quality of foraging grounds matter? Polar Biol 37:665-674

Isaksen K, Gavrilo M (2000) Little auk. In T. Anker-Nilssen et al. (eds.): The status of marine birds breeding in the Barents Sea region. Nor Polarinst Rapp, p 113

Jakubas D, Wojczulanis-Jakubas K, Walkusz W (2007) Response of dovekie to changes in food availability. Waterbirds 30:421-428

Jakubas D, Głuchowska M, Wojczulanis-Jakubas K, Karnovsky NJ, Keslinka L, Kidawa D, Walkusz W, Boehnke R, Cisek M, Kwasniewski S, Stempniewicz L (2011) Different foraging effort does not influence body condition and stress level in little auks. Mar Ecol Prog Ser 432:277-290

Jakubas D, Iliszko L, Wojczulanis-Jakubas K, Stempniewicz L (2012) Foraging by little auks in the distant marginal sea ice zone during the chick-rearing period. Polar Biol 35:73-81

Jakubas D, Trudnowska E, Wojczulanis-Jakubas K, Iliszko L, Kidawa D, Darecki M, Blachowiak-Samolyk K, Stempniewicz L (2013) Foraging closer to the colony leads to faster growth in little auks. Mar Ecol Prog Ser 489:263-278

Karnovsky NJ, Kwasniewski S, Weslawski JM, Walkusz W, Beszczyńska-Möller A (2003) Foraging behaviour of little auks in a heterogenous environment. Mar Ecol Prog Ser 253:289-303

Karnovsky NJ, Hobson KA, Iverson S, Hunt GL Jr (2008) Seasonal changes in the diets of seabirds in the North Water Polynya: a multiple-indicator approach. Mar Ecol Prog Ser 357:291-299

Karnovsky NJ, Harding A, Walkusz W, Kwasniewski S, Goszczko I, Wiktor J Jr, Routii H, Bailey A, McFadden L, Brown Z, Beaugrand G, Grémillet D (2010) Foraging distributions of little auks Alle alle across the Greenland Sea: implications of present and future Arctic climate change. Mar Ecol Prog Ser 415:283-293

Kidawa D, Jakubas D, Wojczulanis-Jakubas K, Stempniewicz L, Trudnowska E, Boehnke R, Keslinka-Nawrot L, Błachowiak- 
Samołyk K (2014) Parental efforts of an Arctic seabird, the little auk (Alle alle), under variable foraging conditions. Mar Biol Res (in press)

Konarzewski M, Taylor JRE, Gabrielsen GW (1993) Chick energy requirements and adult energy expenditures of Dovekies (Alle alle). Auk 110:603-609

Kwasniewski S, Gluchowska M, Jakubas D, Wojczulanis-Jakubas K, Walkusz W, Karnovsky NJ, Blachowiak-Samolyk K, Cisek M, Stempniewicz L (2010) The impact of different hydrographic conditions and zooplankton communities on provisioning little auks along the west coast of Spitsbergen. Prog Oceanogr 87:72-82

Kwasniewski S, Gluchowska M, Walkusz W, Karnovsky NJ, Jakubas D, Wojczulanis-Jakubas K, Harding AMA, Goszczko I, Cisek M, Beszczynska-Möller A, Walczowski W, Weslawski JM, Stempniewicz L (2012) Interannual changes in zooplankton on the West Spitsbergen Shelf in relation to hydrography, and their consequences for the diet of planktivorous seabirds. ICES J Mar Sci 69:890-901

Loeng H, Drinkwater K (2007) An overview of the ecosystems of the Barents and Norwegian Seas and their response to climate variability. Deep-Sea Res II 54:2478-2500

Lønne OJ, Gabrielsen GW (1992) Summer diet of sea birds feeding in sea-ice-covered waters near Svalbard. Polar Biol 12:685-692

Pedersen CE, Falk K (2001) Chick diet of dovekies Alle alle in Northwest Greenland. Polar Biol 24:53-58

Piechura J, Walczowski W (2009) Warming of the West Spitsbergen Current and sea ice north of Svalbard. Oceanologia 51:147-164

Piechura J, Beszczynska-Möller A, Osinski R (2001) Volume, heat and salt transport by the West Spitsbergen Current. Polar Res 20:233-240
Scott CL, Falk-Petersen S, Sargent JR, Hop H, Lonne OJ, Poltermann M (1999) Lipids and trophic interactions of ice fauna and pelagic zooplankton in the marginal ice zone of Barents Sea. Polar Biol 21:65-71

Sokal RR, Rolf FJ (1981) Biometry, 2nd edn. WH Freeman and Company, New York

Steen H, Vogedes D, Broms F, Falk-Petersen S, Berge J (2007) Little auks (Alle alle) breeding in High Arctic Fjord system: bimodal foraging strategies as a response to poor food quality? Polar Res 26:118-125

Stempniewicz L (2001) Alle alle little auk. BWP update. J. Birds West Palearctic 3:175-201

Stempniewicz L, Blachowiak-Samołyk K, Weslawski JM (2007) Impact of climate change on zooplankton communities, seabird populations and arctic terrestrial ecosystem-a scenario. DeepSea Res II 54:2934-2945

Wacasey JW, Atkinson EG (1987) Energy values of marine benthic invertebrates from the Canadian Arctic. Mar Ecol Prog Ser 39:243-250

Węsławski JM, Stempniewicz L, Galaktionov K (1994) Summer diet of seabirds from the Frans Josef Land archipelago, Russian Arctic. Polar Res 13:173-181

Węsławski JM, Stempniewicz L, Mehlum FS (1999) Summer feeding strategy of the little auk (Alle alle) from Bjornoya, Barents Sea. Polar Biol 21:129-134

Wojczulanis K, Jakubas D, Walkusz W, Wennerberg L (2006) Differences in food delivered to chicks by males and females of little auks (Alle alle) on South Spitsbergen. J Ornithol 147:543-548 